\title{
ANALISIS KEMAMPUAN SPASIAL SISWA BERKEMAMPUAN MATEMATIKA TINGGI DALAM MENYELESAIKAN MASALAH GEOMETRI BANGUN RUANG SISI DATAR
}

\author{
Lidia Christine Silalahi ${ }^{1)}$, Muh. Rizal ${ }^{2)}$, Gandung Sugita ${ }^{3)}$ \\ lidiasilalahi644@gmail.com ${ }^{1)}$, rizaltberu97@yahoo.com ${ }^{2)}$,gandungpplw@gmail.com ${ }^{3)}$
}

\begin{abstract}
Abstrak: Penelitian ini bertujuan untuk mendeskripsikan kemampuan spasial siswa kelas VIII SMP Kristen GPID Palu dalam Menyelesaikan Masalah Geometri Bangun Ruang Sisi Datar Berdasarkan Kemampuan Matematika Tinggi. Jenis penelitian ini adalah penelitian studi kasus dengan pendekatan kualitatif. Subjek penelitian yang digunakan dalam penelitian ini adalah siswa yang memiliki kemampuan matematika tinggi (ST). Subjek penelitian diberi tes geometri bangun ruang sisi datar masalah I dan kemudian diwawancara. Untuk menguji kredibilitas data, dilakukan triangulasi waktu dengan memberi tes geometri bangun ruang sisi datar masalah II dan melakukan wawancara. Berdasarkan hasil analisis ditemukan bahwa dalam kemampuan persepsi spasial, ST mampu menentukan kubus-kubus satuan yang terletak di posisi horizontal dan posisi vertikal pada tumpukan kubus setelah dimanipulasi posisinya. Selain itu untuk kemampuan rotasi mental, ST mampu merotasikan posisi kubus dan membayangkan perputaran dari kubus tersebut secara tepat. ST menentukan perubahan kubus setelah diputar $90^{\circ}$ berlawanan arah jarum jam dengan cara membayangkan memutar kubus secara siku-siku ke sebelah kiri. Serta pada kemampuan visualisasi spasial, ST mampu menentukan perubahan kubus kedalam bentuk yang berbeda dan mengenali perubahan posisi dari unsur-unsur kubus tersebut. ST mampu menentukan letak gambar segitiga, lingkaran, dan segiempat yang ada pada jaring-jaring kubus yang memperlihatkan bagian dalam kubus setelah diputar kedua kali.
\end{abstract}

Kata Kunci: Kemampuan matematika, Kemampuan spasial, Geometri bangun ruang sisi datar

\begin{abstract}
This research aims to describe the spatial ability of grade VIII students SMP Kristen GPID Palu in Solving Flat Geometry Problems in Flat-Side Space Based on High. The type of this research is a case study research with a qualitative approach. The subject that use in this research are the students who have high mathematical abilities (ST). The research subjects were given geometry tests to construct a flat side space problem I and then interviewed. To test the credibility of the data, time triangulation was carried out by giving geometry tests to construct the flat side space of problem II and conducting interviews. Based on the results of the analysis it was found that in spatial perception ability, ST were able to determine unit cubes located in the horizontal position and vertical position in the cube stack after being manipulated. Besides that for mental rotation ability, ST is able to rotate the position of the cube and imagine the rotation of the cube correctly. ST determines the change of the cube after being rotated $90^{\circ}$ counterclockwise by imagining rotating the cube right to the left. As well as in spatial visualization ability, ST is able to determine the change of cubes into different forms and recognize changes in position of the elements of the cube. ST is able to determine the location of the triangle, circle, and quadrilateral image in the cube network that shows the inside of the cube after being rotated twice.
\end{abstract}

Keywords: Mathematical Ability, Spatial Ability, Geometry to construct flat side spaces

Geometri merupakan materi pelajaran matematika yang membutuhkan kemampuan matematis yang cukup dan pemahaman istilah dari konsep di dalamnya. Menurut Shadiq (2009), geometri adalah ilmu yang membahas tentang hubungan antara titik, garis, sudut, bidang, dan bangun-bangun ruang. Aisah (2015) menyatakan bahwa tujuan pembelajaran geometri adalah untuk mengembangkan kemampuan keruangan pada dunia nyata dan menunjang pembelajaran matapelajaran yang lain. Belajar geometri berarti belajar berpikir 
kritis matematis yaitu meletakkan struktur hierarki dari konsep-konsep pada tingkat yang lebih tinggi yang dibentuk atas dasar apa yang telah terbentuk sebelumnya. Misalnya ketika siswa dihadapkan pada suatu kubus dan diberi satu konsep jaring-jaring maka siswa dituntut untuk berpikir kritis untuk menemukan jaring-jaring kubus yang lain. National Council of Teachers of Mathematics (Siswanto dan Kusumah, 2017) menyatakan bahwa salah satu standar diberikannya geometri di sekolah adalah agar siswa dapat menggunakan visualisasi, mempunyai kemampuan spasial dan pemodelan geometri untuk menyelesaikan masalah. Aisah (2015) menyatakan bahwa kemampuan memvisualisasikan suatu kejadian ke dalam gambar pada setiap orang berbeda. Hal ini bergantung pada kemampuan spasial yang dimiliki oleh setiap orang, dengan kemampuan spasial yang baik dapat membantu dalam konsep-konsep matematika.

Kemampuan spasial merupakan kemampuan membayangkan suatu objek dalam bangun ruang. Menurut Harmony dan Theis (2012), kemampuan spasial merupakan kemampuan untuk menangkap dunia ruang secara tepat atau dengan kata lain kemampuan untuk memvisualisasikan gambar, yang di dalamnya termasuk kemampuan mengenal bentuk dan benda secara tepat, melakukan perubahan suatu benda dalam pikirannya dan mengenali perubahan tersebut, menggambarkan suatu hal atau benda dalam pikiran dan mengubahnya dalam bentuk nyata, mengungkapkan data dalam bentuk grafik serta kepekaan terhadap keseimbangan, relasi, warna, garis, bentuk, dan ruang. Febriana (2015) mengatakan bahwa kemampuan spasial menyangkut kemampuan mempresentasi, mentransformasi, dan memanggil kembali informasi simbolis. Berdasarkan beberapa pendapat tersebut, maka kemampuan spasial merupakan kemampuan yang dimiliki seseorang dalam melihat hubungan ruang, mempresentasikan, mentransformasikan, dan memanggil kembali informasi simbolik serta kemampuan untuk menggambarkan sesuatu yang ada dalam pikiran dan mengubahnya dalam bentuk nyata.

Maier (1998) mengenalkan lima unsur/elemen dari kemampuan spasial yaitu persepsi spasial (spatial perception), visualisasi spasial (spatial vizualitation), rotasi mental (mental rotation), relasi spasial (spatial relations), dan orientasi spasial (spatial orientation). Menurut Piaget dan Inhelder (Yilmaz, 2009), kemampuan spasial merupakan konsep abstrak yang di dalamnya meliputi hubungan spasial (kemampuan untuk mengamati hubungan posisi objek dalam ruang), kerangka acuan (tanda yang dipakai sebagai patokan untuk menentukan posisi objek dalam ruang), hubungan proyektif (kemampuan untuk melihat objek dari berbagai sudut pandang), konversi jarak (kemampuan untuk memperkirakan jarak antara dua titik), representasi spasial (kemampuan untuk merepresentasikan hubungan spasial dengan memanipulasi secara kognitif), dan rotasi mental (membayangkan perputaran objek dalam ruang), sedangkan Linn dan Petersen (1986) mengelompokkan kemampuan spasial ke dalam tiga kategori yaitu persepsi spasial (spatial perception), rotasi mental (mental rotation), dan visualisasi spasial (spatial vizualitation).

Wai, Lubinski, dan Benbow (2009) menyatakan bahwa kemampuan spasial mempunyai peranan penting dalam mengembangkan keahlian yang berhubungan dengan STEM (Science, Technology, Engineering, and Mathematics) dan pelibatan kemampuan spasial dalam mencari talenta modern akan mengidentifikasi potensi tersembunyi yang berkaitan dengan STEM dari siswa. Sependapat dengan Mohler (2008) yang menyatakan bahwa kemampuan spasial memberikan pengaruh terhadap penguasaan berbagai bidang dan sebagai pemrediksi tentang kesuksesan seseorang dalam berbagai bidang, Yilmaz (2009) mengatakan bahwa pentingnya kemampuan spasial dalam pembelajaran di sekolah dan pekerjaan-pekerjaan tertentu telah diakui secara global oleh para peneliti dalam bidang 
psikologi dan pendidikan. Hal tersebut dapat dilihat dari adanya pembelajaran geometri di sekolah-sekolah dalam berbagai jenjang pendidikan dasar dan menengah, serta tes kemampuan spasial yang menjadi tes wajib dalam berbagai bagian dari tes psikologi ketika seseorang akan menempuh jenjang pendidikan tinggi dan memasuki dunia kerja di perusahaan-perusahaan tertentu.

Demikian pentingnya kemampuan spasial sangat perlu dimiliki oleh siswa, sehingga guru dituntut untuk memperhatikan kemampuan ini dalam pembelajaran di kelas. Namun pada kenyataannya kemampuan spasial yang dimiliki sebagian besar siswa masih lemah. Hal ini terungkap melalui hasil wawancara yang dilakukan peneliti kepada guru matematika yang mengajar di SMP Kristen GPID Palu. Hasil wawancara peneliti dengan guru matematika memberikan informasi bahwa kesulitan yang dihadapi oleh sebagian besar siswa dalam mempelajari bangun ruang sisi datar adalah kesulitan membayangkan atau memberikan gambar tentang bangun ruang sisi datar tersebut. Dari hasil wawancara tersebut juga diperoleh informasi bahwa kesulitan yang dihadapi siswa dalam mempelajari bangun ruang sisi datar berkaitan erat dengan kemampuan matematika yang dimiliki siswa.

Terkait dengan kemampuan spasial, setiap siswa memiliki kemampuan spasial yang berbeda-beda. Hal ini dapat dilihat dari perbedaan kemampuan matematika yang dimiliki setiap siswa. Turgut dan Yilmaz (2012) mengatakan bahwa ada hubungan positif antara kesuksesan akademis dan kemampuan spasial. Siswa yang memiliki prestasi matematika tinggi memiliki kemampuan spasial yang tinggi dibandingkan dengan siswa yang memiliki prestasi matematika sedang dan rendah. Ciri siswa yang mampu dalam bidang matematika adalah memiliki kemampuan spasial yang tinggi. Namun pada kenyataannya, masih banyak siswa yang mempunyai kemampuan spasial yang rendah. Hal ini dapat dilihat dari sulitnya mereka mempelajari materi-materi yang berkaitan dengan geometri khususnya geometri bangun ruang.

Tujuan penelitian ini adalah untuk mendeskripsikan kemampuan spasial siswa kelas VIII SMP Kristen GPID Palu dalam menyelesaikan masalah geometri bangun ruang sisi datar berdasarkan kemampuan matematika tinggi.

\section{METODE PENELITIAN}

Jenis penelitian ini adalah penelitian studi kasus dengan pendekatan kualitatif. Subjek penelitian ini adalah satu orang siswa kelas VIII SMP Kristen GPID Palu yang berkemampuan matematika tinggi. Teknik pengumpulan data menggunakan tes tertulis dan wawancara mendalam. Instrumen penelitian yang digunakan dalam penelitian ini adalah instrumen utama yaitu peneliti sendiri dan instrumen pendukung yaitu tes kemampuan matematika dan tes kemampuan spasial. Analisis data dalam penelitian ini mengacu pada analisis data kualitatif menurut Miles, Hubermen dan Saldana (2014), yaitu: Kondensasi Data (Data Condensation), Penyajian Data (Data Display), dan Penarikan Kesimpulan (Conclusion Drawing).

\section{HASIL PENELITIAN}

Pemilihan subjek berdasarkan kemampuan matematika tinggi yaitu sebanyak 2 orang, kemudian dipilih 1 orang sebagai subjek penelitian. Uji kredibilitas dilakukan menggunakan triangulasi waktu, dengan memberikan dua kali tes tertulis dengan soal yang memiliki tingkat kesulitan setara pada waktu yang berbeda dan uji kredibilitas dilakukan 
menggunakan member-check. Subjek menyelesaikan kedua tes tertulis tersebut dan telah kredibel, data yang diolah adalah data pada tes masalah I.

\section{Jawaban subjek berkemampuan tinggi (ST)} berikut:

Hasil tes tertulis dalam menyelesaikan soal pertama masalah I adalah sebagai

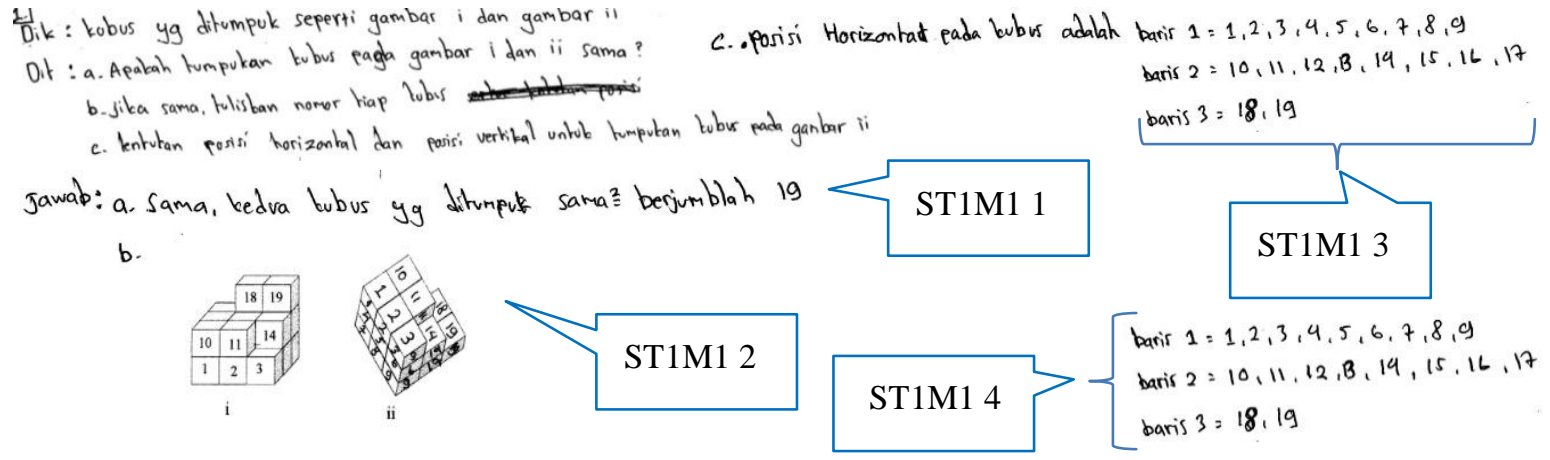

Gambar 1. Jawaban ST untuk soal 1 masalah I

Hasil pekerjaan pada gambar 1 dapat dijelaskan bahwa ST mengetahui perubahan posisi tumpukan kubus pada gambar i setelah dimanipulasi, hal ini diketahui karena ST mengatakan bahwa gambar i dan gambar ii sama (ST1M1 1) dan ST mampu menentukan perubahan posisi tumpukan kubus setelah dimanipulasi dengan cara menentukan susunan tiap-tiap kubus satuan pada gambar ii yaitu kubus satuan 1, 2, 3, 4, 5, 6, 7, 8, 9, 10, 11, 14, 17, 18, 19 (ST1M1 2). ST juga mampu menentukan tumpukan kubus yang terletak pada posisi horizontal setelah dimanipulasi dengan menyebutkan kubus satuan yang terletak pada baris pertama yaitu kubus satuan $1,2,3,4,5,6,7,8$, 9, baris kedua yaitu kubus satuan 10, 11, 12, 13, 14, 15, 16, 17, dan baris ketiga yaitu kubus satuan 18, 19 (ST1M1 3), serta ST mampu menentukan tumpukan kubus yang terletak pada posisi vertikal setelah dimanipulasi dengan menyebutkan kubus satuan yang terletak pada kolom pertama yaitu kubus satuan 1, 4, 7, 10, 12, 15, kolom kedua yaitu kubus satuan 2, 5, 8, 11, 13, 16, 18, dan kolom ketiga yaitu kubus satuan 3, 6, 9, 14, 17, 19 (ST1M1 4).

Hasil wawancara dalam menyelesaikan soal pertama masalah I antara peneliti dengan ST adalah sebagai berikut:

ST1M1009P : Apa yang diketahui dari soal?

ST1M1010S : Beberapa kubus ditumpuk seperti gambar i dan ii.

ST1M1015P : Apa yang ditanyakan dari soal nomor 1?

ST1M1016S : Yang pertama, apakah tumpukan kubus pada gambar i dan ii sama. Yang kedua, jika sama maka tuliskan nomor tiap kubus. Yang ketiga, tentukan posisi horizontal dan posisi vertikal untuk tumpukan kubus pada gambar ii.

ST1M1025P : Apa jawabanmu nomor 1?

ST1M1026S : Untuk bagian a) apakah tumpukan kubus pada gambar i dan gambar ii sama? Jawaban saya sama dan masing-masing tumpukan kubus berjumlah 19. Untuk bagian b) jika sama, tuliskan nomor tiap kubus. Saya sudah tuliskan nomor pada tiap-tiap kubus pada gambar ii, dan untuk bagian c) tentukan posisi horizontal dan posisi vertikal untuk tumpukan kubus pada gambar ii. Jawaban saya yaitu posisi horizontal 
pada tumpukan kubus adalah baris pertama 1, 2, 3, 4, 5, 6, 7, 8, dan 9; baris kedua 10, 11, 12, 13, 14, 15, 16, dan 17; dan baris ketiga 18 dan 19. Terus, posisi vertikal pada tumpukan kubus adalah kolom pertama $1,4,7,10,12$, dan 15; kolom kedua 2, 5, 8, 11, 13, 16, dan 18; dan kolom ketiga 3, 6, 9, 14, 17, dan 19.

ST1M1059P : Oh iya, bagaimana adik tahu kalau tumpukan kubus gambar i sama dengan tumpukan kubus gambar ii?

ST1M1060S : Kalau diperhatikan gambar i dan gambar ii sama. Kalau tumpukan kubus di gambar i dimiringkan bagian bawahnya sedikit ke kanan dan dimiringkan lagi lagi sedikit ke belakang, maka gambar i akan sama seperti gambar ii, dan kalau dihitung juga banyak kubus gambar i sama dengan banyak kubus gambar ii yaitu 19 .

ST1M1051P : Bagaimana adik tahu kalau tumpukan kubus gambar ii itu terdiri dari kubus 1 sampai 19?

ST1M1052S : Karena kalau kita lihat dari tumpukan kubus gambar i kan ada beberapa kubus yang tidak diberi nomor toh, tapi kalau kita hitung kubusnya dari nomor 1, 2, 3, ke belakang, terus dari nomor 10, 11, kebelakang lagi hingga nomor 18 dan 19, itu nomornya berurutan, hanya saja ada yang tidak diberi nomor dan ada yang tidak kelihatan. Begitu. Jadi pada saat di soal disuruh tuliskan nomor tiap kubus, saya tulis semua nomor pada kubus yang terlihat sesuai urutan.

ST1M1053P : Tapi itu adik tulis kubus 10, 11, terus langsung 14.

ST1M1054S : Itu karena masih ada lagi kubus yang disusun hanya saja tidak kelihatan tapi sebenarnya ada dan berurutan. Di belakang nomor 10 ada nomor 12 dan di belakang nomor 11 ada nomor 13 dan di samping nomor 13 itu nomor 14. Begitu.

ST1M1027P : Jadi, bagaimana adik tahu kalau tumpukan kubus gambar ii yang baris paling bawah atau baris pertama menurutmu itu kubus 1, 2, 3, 4, 5, 6, 7, 8, dan 9?

ST1M1030S : Kan dari gambar i itu pada baris pertama banyak kubus yang kelihatan itu kubus 1, 2, dan 3 toh, padahal di belakang kubus 1, 2, dan 3 masih ada lagi kubus tetapi tidak kelihatan. Nah kalau tumpukan kubusnya dimiringkan maka bagian bawah tumpukan kubus tersebut akan kelihatan seperti pada gambar ii. Kubus-kubus baris pertama itu kelihatan semua dan banyak kubusnya ada 9.

ST1M1031P : Terus, bagaimana adik tahu kalau tumpukan kubus gambar ii yang baris di tengah atau baris kedua menurutmu itu kubus 10, 11, 12, 13, $14,15,16$, dan 17 ?

ST1M1032S : Karena baris pertama pada gambar ii yaitu kubus 1, 2, 3, 4, 5, 6, 7, 8, dan 9, maka baris kedua pada gambar ii adalah tumpukan kubus yang berada tepat di atas kubus pada baris pertama yaitu 10, 11, 12, 13, 14, 15, 16, dan 17.

ST1M1033P : Tapi di tumpukan kubus gambar ii tidak ada kubus 12, 13, 15, dan 16 hanya $10,11,14$, dan 17.

ST1M1036S : Ee begini, kalau kita perhatikan gambar i, di belakang kubus nomor 10 itu ada dua kubus yang disusun ke belakang. Nah kubus nomor 11 juga ada dua kubus yang disusun ke belakang hanya saja kubus yang satunya tertutup kubus yang nomor 18. Kalau di gambar ii itu saya 
tahu kalau di belakang kubus nomor 10 itu ada dua kubus yang disusun ke belakang dari kubus yang nomor 4 dan 7 , karena di atas kubus nomor 1 ada kubus nomor 10 berarti di atas kubus nomor 4 ada kubus nomor 12 dan di atas kubus nomor 7 ada kubus nomor 15 . Begitu juga untuk kubus yang nomor 11 kalau digambar ii saya tau ada kubus lagi yang disusun ke belakang dari kubus nomor 5 dan 8. Kalau di atas kubus nomor 2 ada kubus nomor 11 berarti di atas kubus nomor 5 ada kubus nomor 13 dan di atas kubus nomor 8 ada kubus nomor 16.

ST1M1037P : Bagaimana adik tahu kalau tumpukan kubus baris ketiga itu kubus 18 dan 19?

ST1M1038S : Karena tumpukan kubus gambar i yang baris ketiganya itu kubus nomor 18 dan 19. Kubus nomor 18 dan 19 pada gambar ii sudah sesuai dengan kubus pada gambar i hanya saja posisinya dimiringkan pada gambar ii.

ST1M1039P : Nah sekarang, bagaimana adik tahu kalau kubus kolom sebelah kiri atau kolom pertama menurutmu itu kubus 1, 4, 7, 10, 12, dan 15?

ST1M1040S : Sama kayak melihat kubus untuk menentukan baris tadi. Pertama kita lihat gambar i, pada kubus nomor 1 dan 10 ada beberapa kubus ditumpuk ke belakang, kemudian saya bayangkan tumpukan kubus di gambar i dimiringkan sesuai dengan gambar ii dan setelah saya beri nomor pada gambar ii yang merupakan tumpukan kubus kolom pertama yaitu $1,4,7,10,12$, dan 15 .

ST1M1041P : Tapikan pada gambar ii tidak ada kubus 12 dan 15.

ST1M1044S : Karena di atas kubus nomor 1 ada kubus nomor 10 berarti di atas kubus nomor 4 ada kubus nomor 12 dan di atas kubus nomor 7 ada kubus nomor 15.

ST1M1045P : Bagaimana adik tahu kalau tumpukan kubus kolom ditengah atau tumpukan kubus kedua menurutmu itu kubus 2, 5, 8, 11, 13, 16, dan $18 ?$

ST1M1048S : Itu ee, saya lihat gambar i, pada kubus nomor 2 dan 11 ada beberapa kubus ditumpuk ke belakang kemudian saya bayangkan tumpukan kubus di gambar i dimiringkan sesuai dengan gambar ii dan setelah saya beri nomor pada gambar ii, yang merupakan tumpukan kubus kolom kedua yaitu 2, 5, 8, 11, 13, 16, dan 18. Nah karena pada gambar ii kubus nomor 13 dan 16 tidak kelihatan, jadi saya tahu ada kubus nomor 13 dan 16 itu karena di atas kubus nomor 2 ada kubus nomor 11 berarti di atas kubus nomor 5 ada kubus nomor 13 dan di atas kubus nomor 8 ada kubus nomor 16.

ST1M1049P : Nah terakhir, bagaimana adik tahu kalau tumpukan kubus kolom sebelah kanan atau tumpukan kubus kolom ketiga menurutmu itu kubus 3, 6, 9, 14, 17, dan 19?

ST1M1050S : Karena tumpukan kubus gambar i yang kolom ketiga itu yang diberi nomor hanya kubus nomor 3, 14, dan 19 toh, tapi sebenarnya jika diteruskan di belakang nomor 3 itu ada kubus nomor 6 dan 9 begitu juga kubus nomor 14 di belakangnya ada kubus nomor 17. Lalu saya bayangkan tumpukan kubus di gambar i dimiringkan sesuai dengan gambar ii, sehingga pada saat saya memberi nomor pada gambar ii saya tulis nomor 6 dan 9 pada kubus yang ada di belakang kubus 3 dan 
nomor 17 pada kubus yang ada di belakang kubus nomor 14 .

Berdasarkan data wawancara tersebut, dapat diketahui bahwa ST dalam menyelesaikan soal pertama masalah I, yaitu:

(a) ST mengetahui tumpukan kubus di gambar i dan ii sama dengan cara membayangkan tumpukan kubus gambar i dimiringkan sedikit ke kanan dan sedikit ke belakang hingga posisinya terlihat sama seperti tumpukan kubus gambar ii, serta mengetahui tumpukan kubus gambar ii sama dengan tumpukan kubus gambar i dengan cara menghitung banyak kubus satuan pada kedua gambar tersebut [ST1M1026S dilanjutkan ST1M1060S].

(b) ST mengetahui susunan tumpukan kubus setelah dimanipulasi dengan cara menghitung tumpukan kubus pada gambar i secara berurutan berdasarkan susunan kubus satuan yang ada pada tumpukan kubus yang terlihat, kemudian menuliskan tiaptiap kubus satuan pada tumpukan kubus di gambar ii secara berurutan sesuai dengan urutan kubus satuan pada gambar i [ST1M1052S dilanjutkan ST1M1054S].

(c) ST mampu menentukan tumpukan kubus satuan yang terletak di posisi horizontal pada tumpukan kubus setelah dimanipulasi, hal ini diketahui karena ST mampu menyebutkan kubus-kubus satuan yang terletak di posisi horizontal pada tumpukan kubus gambar ii [ST1M1026S]. ST mengetahui beberapa tumpukan kubus pada baris paling bawah dengan cara membayangkan tumpukan kubus pada gambar i dimiringkan sehingga akan sama seperti tumpukan kubus pada gambar ii dan menghitung banyak kubus satuan baris paling bawah pada tumpukan kubus gambar ii [ST1M1030S]. ST mengetahui beberapa tumpukan kubus pada baris di tengah dengan cara melihat tumpukan kubus yang berada tepat di atas tumpukan kubus baris paling bawah [ST1M1032S] dan mampu mengetahui kubus satuan yang tidak terlihat pada tumpukan kubus baris di tengah dengan cara membayangkan kubus satuan baris di tengah yang tidak terlihat yang berada tepat di atas kubus satuan baris paling bawah [ST1M1036S]. ST mengetahui beberapa tumpukan kubus pada baris paling atas dengan cara mencocokkan posisi kubus yang berada pada baris paling atas di gambar i yang telah dimiringkan dengan kubus yang berada pada gambar ii [ST1M1038S]. ST juga mampu menentukan tumpukan kubus yang terletak di posisi vertikal pada tumpukan kubus setelah dimanipulasi, hal ini diketahui karena subjek ST mampu menyebutkan kubus-kubus satuan yang terletak di posisi vertikal pada tumpukan kubus gambar ii [ST1M1026S]. Subjek ST mengetahui beberapa tumpukan kubus pada kolom sebelah kiri dengan cara melihat tumpukan kubus pada gambar i yang merupakan kolom sebelah kiri, kemudian mencocokkan posisi kubus satuan yang berada di kolom sebelah kiri pada gambar i yang telah dimiringkan dengan posisi kubus satuan yang berada pada gambar ii [ST1M1040S] dan mampu mengetahui kubus satuan yang tidak terlihat pada tumpukan kubus kolom sebelah kiri dengan cara membayangkan kubus satuan kolom sebelah kiri yang tidak terlihat yang berada tepat di atas kubus satuan baris paling bawah [ST1M1044S]. ST mengetahui beberapa tumpukan kubus pada kolom di tengah dengan cara melihat tumpukan kubus pada gambar i yang merupakan kolom di tengah, kemudian mencocokkan posisi kubus satuan yang berada di kolom di tengah pada gambar i yang telah dimiringkan dengan kubus satuan yang berada pada gambar ii dan mampu mengetahui kubus satuan yang tidak terlihat pada tumpukan kubus kolom di tengah dengan cara membayangkan kubus satuan kolom di tengah yang tidak terlihat yang berada tepat di atas kubus satuan baris paling bawah [ST1M1048S]. ST mengetahui beberapa tumpukan kubus 
pada kolom sebelah kanan dengan cara memiringkan tumpukan kubus pada gambar i sesuai dengan gambar ii, kemudian mencocokkan posisi kubus satuan yang berada pada kolom sebelah kanan di gambar i yang telah dimiringkan dengan kubus satuan yang berada pada gambar ii [ST1M1050S].

Hasil tes tertulis dalam menyelesaikan soal kedua masalah I adalah sebagai berikut:

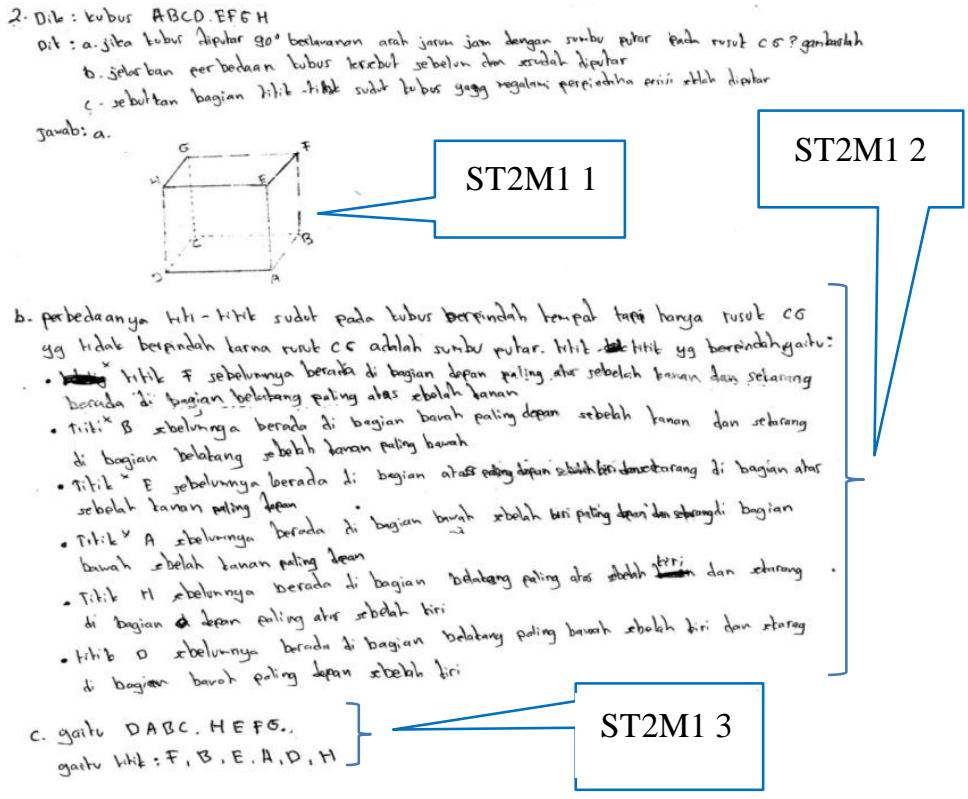

Gambar 2. Jawaban ST untuk soal kedua masalah I

Hasil pekerjaan pada gambar 2 dapat dijelaskan bahwa ST mampu merotasi suatu kubus secara tepat, hal ini diketahui karena ST menggambar kubus yang telah diputar $90^{\circ}$ berlawanan arah jarum jam dengan sumbu putar pada rusuk CG secara benar (ST2M1 1). ST juga mampu membayangkan perputaran suatu kubus secara tepat, hal ini diketahui karena ST menjelaskan dengan benar perbedaan kubus tersebut sebelum dan sesudah diputar. Dalam hal ini ST menjelaskan perbedaan titik-titik sudut pada kubus berpindah tempat tetapi hanya rusuk $\mathrm{CG}$ yang tidak berpindah posisi karena rusuk CG adalah sumbu putar (ST2M1 2), serta ST mampu menyebutkan dengan benar titik-titik sudut yang mengalami perpindahan posisi setelah diputar dengan menuliskan titik-titik sudut F, B, E, A, D, H (ST2M1 3).

Hasil wawancara dalam menyelesaikan soal kedua masalah I antara peneliti dengan ST adalah sebagai berikut:

ST2M1033P : Bagaimana adik mengerjakan soalnya hingga adik jawab kubus tersebut setelah diputar menjadi kubus DABC.HEFG?

ST2M1034S : Saya bayangkan kubusnya saya putar $90^{\circ}$ berlawanan arah jarum jam atau ke sebelah kiri.

ST2M1035P : Bagaimana adik tahu kalau kubus itu kau putar 90?

ST2M1036S : Karena saya putar kubusnya secara siku-siku.

ST2M1039P : Oh iya, kenapa adik bilang tadi kubus diputar berlawanan arah jarum jam sama saja kubus tersebut diputar ke sebelah kiri?

ST2M1040S : Begini, misalnya jam dinding ditaruh di meja toh. Kalau diperhatikan jarumnya berputar ke sebelah kanan. Jadi kalau kubus diputar berlawanan arah jarum jam, sama saja kubusnya diputar ke sebelah kiri.

ST2M1041P : Apa jawabanmu sebelum dan sesudah kubus tersebut diputar?

ST2M1042S : Perbedaannya itu titik-titik sudut pada kubus berpindah tempat tapi hanya rusuk $\mathrm{CG}$ yang tidak berpindah karena rusuk $\mathrm{CG}$ adalah sumbu putar.

ST2M1043P : Maksudnya berpindah tempat? 
ST2M1044S : Maksudnya itu titik-titik sudutnya berpindah tempat. Seperti titik F sebelumnya berada di bagian depan paling atas sebelah kanan dan setelah diputar berada di bagian belakang paling atas sebelah kanan, titik B sebelumnya berada di bagian depan paling bawah sebelah kanan setelah diputar berada di bagian belakang paling bawah sebelah kanan, titik E sebelumnya berada di bagian depan paling atas sebelah kiri dan setelah diputar berada di bagian depan paling atas sebelah kanan, titik A sebelumnya berada dibagian depan paling bawah sebelah kiri dan setelah diputar berada di bagian depan paling bawah sebelah kanan, titik $\mathrm{H}$ sebelumnya berada di bagian belakang paling atas sebelah kiri dan setelah diputar berada di bagian depan paling atas sebelah kiri, dan titik D sebelumnya berada di bagian belakang paling bawah sebelah kiri dan setelah diputar berada di bagian bawah paling depan sebelah kiri.

ST2M1045P : Titik C dan G?

ST2M1048S : Tidak berpindah posisi, karena rusuk CG merupakan sumbu putar. Kalau sumbu putar itu posisinya tetap.

ST2M1055P : Jadi bagian titik-titik sudut kubus yang mengalami perpindahan posisi itu apa saja?

ST2M1056S : Yaitu titik F, B, E, A, D, dan H.

Berdasarkan data wawancara tersebut, dapat diketahui bahwa ST dalam menyelesaikan soal kedua masalah I, yaitu:

(a) ST mengetahui cara memutar kubus $90^{\circ}$ dengan membayangkan memutar kubus secara siku-siku [ST2M1038S] dan mengetahui cara memutar kubus berlawanan arah jarum jam dengan membayangkan memutar kubus tersebut ke kiri [ST2M1040S].

(b) ST mengetahui perbedaan kubus tersebut sebelum dan sesudah diputar [ST2M1042S] dan mampu menjelaskan perbedaan kubus tersebut sebelum dan sesudah kubus tersebut diputar [ST2M1044S]. ST mampu menjelaskan mengapa sumbu putar pada kubus tersebut berubah posisi setelah diputar $90^{\circ}$ berlawanan arah jarum jam [ST2M1046S], serta ST mampu menyebutkan dengan benar bagian kubus yang mengalami perpindahan posisi setelah diputar dengan menyebutkan titik-titik sudut kubus tersebut yang mengalami perpindahan posisi [ST2M1056S].

Hasil tes tertulis dalam menyelesaikan soal ketiga masalah I adalah sebagai berikut:

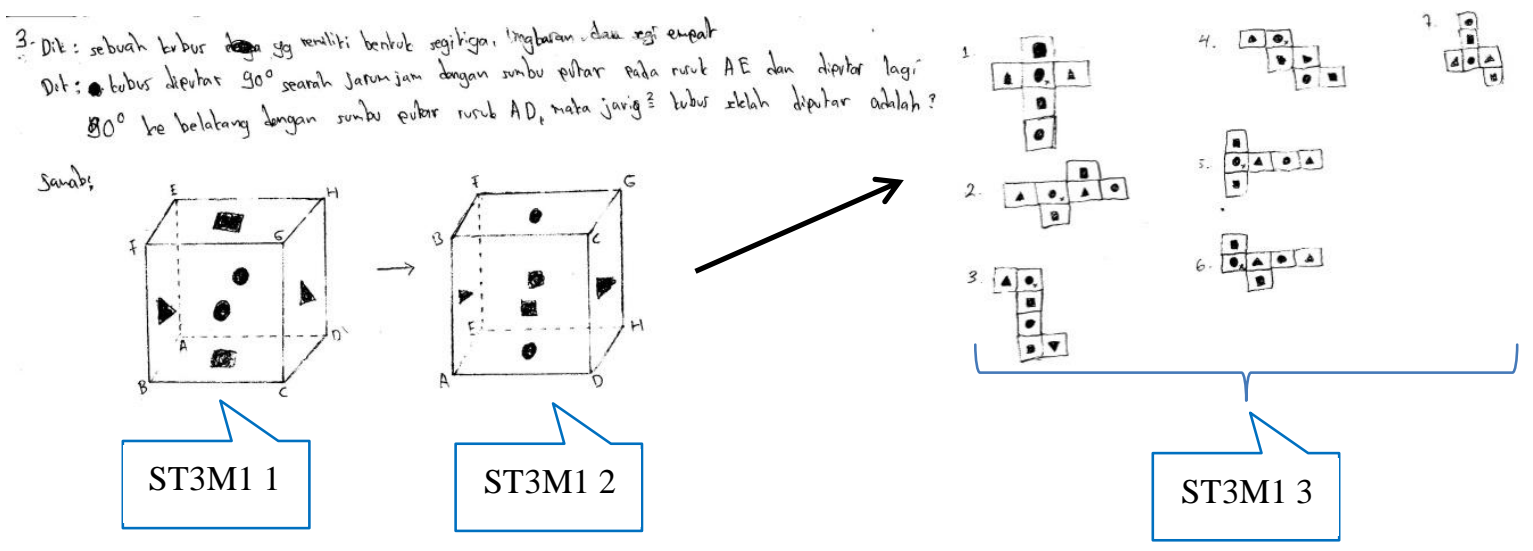

Gambar 3. Jawaban ST untuk soal ketiga masalah I 
Hasil pekerjaan pada gambar 3 dapat dijelaskan bahwa ST mampu melihat komposisi suatu kubus secara tepat. Hal ini diketahui karena ST mampu menggambar kubus yang telah diputar $90^{\circ}$ searah jarum jam dengan sumbu putar pada rusuk AE dan mampu menentukan letak segitiga, segiempat, dan lingkaran secara benar (ST3M1 1), ST juga mampu menggambar kubus yang telah diputar $90^{\circ}$ ke belakang dengan sumbu putar pada rusuk $\mathrm{AD}$ dan menentukan letak segitiga, segiempat, dan lingkaran secara benar (ST3M1 2), serta ST mampu menentukan jaring-jaring kubus setelah diputar kedua kali, ST menggambar 7 jaring-jaring kubus dan menentukan letak segitiga, segiempat, dan lingkaran pada jaring-jaring kubus tersebut yang memperlihatkan bagian dalam kubus secara tepat (ST3M1 3).

Hasil wawancara dalam menyelesaikan soal ketiga masalah I antara peneliti dengan ST adalah sebagai berikut:

ST3M1031P : Bagaimana adik putar kubusn4ya $90^{\circ}$ searah jarum jam?

ST3M1032S : Karena jarum jam berputar ke sebelah kanan maka kubusnya saya putar ke sebelah kanan.

ST3M1033P : Bagaimana kubusnya adik putar $90^{\circ}$ ?

ST3M1034S : Kubusnya tinggal saya putar membentuk sudut siku-siku.

ST3M1039P : Saat adik putar kubusnya pertama kali, apa yang terjadi?

ST3M1040S : Kubus tersebut berpindah posisi, bidang ABFE yang tadinya di depan berpindah ke sebelah kiri, bidang BCGF yang tadinya di kanan berpindah ke depan, bidang CDHG yang tadinya di belakang berpindah ke kanan, dan bidang ADHE yang tadinya di kiri berpindah ke belakang.

ST3M1041P : Terus untuk bidang ABCD dan bidang EFGH?

ST3M1042S : Bidang ABCD dan bidang EFGH posisinya tetap.

ST3M1045P : Saat adik putar kubusnya, apakah semua bagian kubus tersebut berpindah posisi?

ST3M1046S : Hanya rusuk AE tidak berpindah posisi. Tapi rusuk AE ikut berputar juga hanya saja posisinya tetap karena rusuk AE hanya berputar ditempat. Karena rusuk AE sumbu putarnya.

ST3M1037P : Bagaimana adik putar kubusnya $90^{\circ}$ ke belakang?

ST3M1038S : Tinggal saya putar saja kubusnya ke belakang secara siku-siku.

ST3M1049P : Saat adik putar kubusnya yang kedua kali, apa yang terjadi?

ST3M1050S : Jadi untuk kubus saya putar yang kedua kali itu saya putar lagi kubus yang sudah saya putar yang pertama tadi. Jadi saat kubusnya saya putar yang kedua kali, kubus tersebut berpindah posisi. Bidang BCGF yang tadinya di depan berpindah ke atas, bidang FGHE yang tadinya di atas berpindah ke belakang, bidang ADHE yang tadinya di belakang berpindah ke bawah, dan bidang BCDA yang tadinya di bawah berpindah ke depan.

ST3M1051P : Terus untuk bidang ABFE dan bidang CDHG?

ST3M1052S : Bidang ABFE dan bidang CDHG posisinya tetap.

ST3M1055P : Saat adik putar kubusnya, apakah semua bagian kubus tersebut berpindah posisi?

ST3M1056S : Hanya rusuk AD tidak berpindah posisi. Tapi rusuk AD ikut berputar juga hanya saja posisinya tetap karena rusuk AD hanya berputar ditempat. Karena rusuk AE sumbu putarnya. 
ST3M1059P : Setelah itu apa lagi?

ST3M1060S : Kemudian saya buat jaring-jaring kubus dan saya tentukan letak posisi gambar segitiga, lingkaran, dan segiempat pada jaring-jaring kubus tersebut.

ST3M1061P : Berapa banyak jaring-jaring kubus yang adik buat?

ST3M1062S : Ada 7 jaring-jaring kubus saya buat.

ST3M1067P : Bagaimana adik menentukan letak gambar segitiga, lingkaran, dan segiempat pada jaring-jaring kubus yang adik buat?

ST3M1068S : Nah pada saat kubusnya sudah saya putar ke belakang letak segitiga yang awalnya ada di bagian depan dan belakang kubus sekarang sudah berada dibagian kiri dan kanan kubus, letak lingkaran yang awalnya ada dibagian kiri dan kanan kubus sekarang sudah berada dibagian atas dan bawah kubus, juga letak segiempat yang awalnya ada di bagian atas dan bawah kubus sekarang sudah berada di bagian depan dan belakang.

ST3M1069P : Terus?

ST3M1070S : Pada saat saya ingin menentukan letak posisi segitiga, lingkaran, dan segiempat di jaring-jaring kubusnya sambil saya bayangkan kalau jaring-jaring kubusnya saya bentuk kembali menjadi kubus maka posisi segitiga, lingkaran, dan segiempat sudah sesuai dengan posisi segitiga, lingkaran, dan segiempat pada kubus yang saya putar kedua kalinya.

Berdasarkan data wawancara tersebut, dapat diketahui bahwa ST dalam menyelesaikan soal ketiga masalah I, yaitu:

(a) ST mampu memutar kubus $90^{\circ}$ searah jarum jam dengan cara membayangkan kubus tersebut diputar ke kanan membentuk sudut siku-siku [ST3M1034S dilanjutkan ST3M1036S], serta mengetahui perubahan kubus tersebut setelah diputar $90^{\circ}$ searah jarum jam [ST3M1040S] dan mampu menjelaskan perubahan posisi kubus tersebut setelah diputar pertama kali [ST3M1042S dilanjutkan ST3M1046S]. ST juga mampu memutar kubus $90^{\circ}$ ke belakang dengan cara membayangkan kubus tersebut diputar ke belakang membentuk sudut siku-siku [ST3M1038S], serta ST mengetahui perubahan kubus tersebut setelah diputar $90^{\circ}$ ke belakang [ST3M1050S] dan mampu menjelaskan perubahan posisi kubus tersebut setelah diputar untuk kedua kali [ST3M1052S dilanjutkan ST3M1056S].

(b) ST mampu menentukan jaring-jaring kubus setelah diputar $90^{\circ}$ searah jarum jam dan diputar lagi $90^{\circ}$ ke belakang dengan cara membuat jaring-jaring kubus dan menentukan letak segitiga, segiempat, dan lingkaran pada jaring-jaring kubus yang telah diputar kedua kali [ST3M2060S dilanjutkan ST3M1062S], serta mampu menentukan letak gambar segitiga, segiempat, dan lingkaran yang berada pada jaringjaring kubus tersebut yang memperlihatkan bagian dalam kubus setelah diputar kedua kali [ST3M1068S] dan untuk memastikan letak gambar segitiga, segiempat, dan lingkaran yang ada pada jaring-jaring kubus sudah sesuai, maka ST membayangkan jaring-jaring kubus tersebut dibentuk kembali menjadi kubus [ST3M1072S].

\section{PEMBAHASAN}

Pada analisis data diperoleh bahwa ST menyelesaikan masalah yang berkaitan dengan persepsi spasial terutama dalam menentukan posisi horizontal dan posisi vertikal 
pada tumpukan kubus setelah dimanipulasi. ST mampu menentukan kubus-kubus yang terletak di posisi horizontal dan posisi vertikal pada tumpukan kubus setelah dimanipulasi serta mampu menyebutkan kubus-kubus yang berada pada posisi horizontal dan posisi vertikal. Hal ini sesuai dengan pendapat Ferisdianto (2014) bahwa subjek berkemampuan matematika tinggi memiliki kemampuan menghitung bangun ruang yang diletakkan posisi horizontal atau vertikal. ST juga menyelesaikan masalah yang berkaitan dengan rotasi mental terutama dalam menentukan perubahan kubus tersebut setelah diputar $90^{\circ}$ berlawanan arah jarum jam dengan cara membayangkan memutar kubus secara siku-siku ke kiri. Azustiani (2017) berpendapat bahwa subjek berkemampuan matematika tinggi mampu merotasikan posisi suatu objek dan mampu menjelaskan bagaimana merotasikan suatu objek, serta ST menyelesaikan masalah yang berkaitan dengan visualisasi spasial terutama dalam menentukan jaring-jaring kubus setelah diputar $90^{\circ}$ searah jarum jam dan diputar lagi $90^{\circ}$ ke belakang dengan cara membuat jaring-jaring kubus dan menentukan letak segitiga, lingkaran, dan segiempat pada jaring-jaring kubus setelah kubus tersebut diputar kedua kali. Hal ini sesuai dengan pendapat Azustiani (2017) bahwa subjek berkemampuan matematika tinggi dapat menentukan jaring-jaring dari suatu kubus, serta ST mampu menentukan letak gambar segitiga, lingkaran, dan segiempat yang ada pada jaring-jaring kubus tersebut yang memperlihatkan bagian dalam kubus setelah diputar kedua kali. Hal ini sesuai dengan pendapat Ferisdianto (2014) bahwa subjek berkemampuan matematika tinggi memiliki kemampuan menunjukkan perubahan atau perpindahan dari suatu kubus, dengan cara mengubah kubus menjadi jaring-jaring dan menentukan gambar pada jaring-jaring tersebut.

\section{KESIMPULAN}

Berdasarkan hasil penelitian dan pembahasan, maka dapat disimpulkan bahwa hasil analisis kemampuan spasial siswa yang berkemampuan matematika tinggi (ST) dalam menyelesaikan geometri bangun ruang sisi datar yaitu untuk kemampuan persepsi spasial (spatial perception), ST mampu menentukan kubus-kubus satuan yang terletak di posisi horizontal dan posisi vertikal pada tumpukan kubus setelah dimanipulasi posisinya. Pada kemampuan rotasi mental (mental rotation), ST mampu merotasikan posisi kubus dan membayangkan perputaran dari kubus tersebut secara tepat. ST menentukan perubahan kubus setelah diputar $90^{\circ}$ berlawanan arah jarum jam dengan cara membayangkan memutar kubus secara siku-siku ke sebelah kiri, serta pada kemampuan visualisasi spasial (spatial vizualitation), ST mampu menentukan perubahan kubus kedalam bentuk yang berbeda dan mengenali perubahan posisi dari unsur-unsur kubus tersebut. ST mampu menentukan letak gambar segitiga, lingkaran, dan segiempat yang ada pada jarng-jaring kubus yang memperlihatkan bagian dalam kubus setelah diputar kedua kali.

\section{SARAN}

Berdasarkan hasil penelitian yang telah diperoleh, beberapa saran yang perlu disampaikan oleh peneliti yaitu guru hendaknya memberikan latihan-latihan soal kepada siswa guna mengembangkan kemampuan spasial yang dimiliki, terutama kepada siswa yang memiliki kemampuan matematika sedang dan rendah dalam mengembangkan kemampuan presepsi spasial, kemampuan rotasi mental, dan kemampuan visualisasi spasial, serta guru juga sebaiknya menciptakan pembelajaran geometri bangun ruang khususnya bangun ruang sisi datar yang interaktif, misalnya pembelajaran dengan menggunakan alat peraga atau perangkat lunak komputer dapat digunakan untuk melatih 
kemampuan membayangkan dan merepresentasikan bentuk objek-objek geometri bangun ruang sisi datar. Bagi peneliti lain diharapkan dapat memperhatikan kesesuaian soal yang akan digunakan untuk melihat kemampuan spasial siswa.

\section{DAFTAR PUSTAKA}

Aisah, W. (2015). Profil Kemampuan Spasial Siswa SMP pada Materi Geometri Bangun Ruang Sisi Datar Ditinjau dari Kemampuan Rigorous Mathematical Thinking (RMT) di SMPN 1 Sidoarjo. Skripsi Universitas Islam Negeri Sunan Ampel Surabaya. [Online]. Tersedia: https://goo.gl /images/Q3EN2d. [10 Februari 2018].

Azustiani, H. (2017). Kemampuan Spasial Siswa SMP kelas VIII Ditinjau dari Kemampuan Matematika Siswa. Jurnal Vol. 1 No. 5. [Online]. Tersedia: http://conferences.uinmalang.ac.id/index.php/SIMANIS/article. [27 Juni 2018]

Febriana, E. (2015). Profil Kemampuan Spasial Siswa Menengah Pertama (SMP) dalam Menyelesaikan Masalah Geometri Dimensi Tiga Ditinjau dari Kemampuan Matematika. Jurnal Elemen Vol. 1 No. 1. [Online]. Tersedia: http://ejournal.hamzanwadi.ac.id/index.php/jel/article. [1 Desember 2017].

Ferisdianto, D. (2014). Profil Kemampuan Spasial Siswa SMP dalam Menyelesaikan Masalah Geometri Ditinjau dari Perbedaan Kemampuan Matematika. Jurnal Ilmiah Pendidikan Matematika Vol. 3 No. 2. [Online]. Tersedia: http://jurnalmahasiswa. unesa.ac.id/article/11615/30/article.pdf. [1 Desember 2017].

Harmony, J., dan Theis, R. (2012). Pengaruh Kemampuan Spasial Terhadap Hasil Belajar Matematika Siswa Kelas VII SMP Negeri 19 Kota Jambi. Edumatika Vol. 02 No. 1. [Online]. Tersedia: http://download.portalgaruda.org/.[22 November 2017].

Linn, M.C., dan Petersen, A.C. (1986). Emergence and Characterization of Sex Differences in Spatial Ability: A Meta-Analysis. [Online]. Tersedia: http://citeseerx.ist.psu.edu/ viewdoc/download. [10 Februari 2018].

Miles, M.B., Hubermen, A.M., dan Saldana, J. (2014). Qualitative Data Analysis: A Methods Sourcebook (Third ed). Amerika:SAGE Publications.

Maier, P.H. (1998). Spatial Geometry and Spatial Ability - How to make solid Geometry solid?, Annual Conference of Didactics of Mathematics 1996. [Online]. Tersedia: http://www.fmd.uni-osnabruek.de/ebooks/gdm/.pdf. [1 Desember 2017].

Mohler, J.L. (2008). A Review of Spatial Ability Research. Engineering Design Graphics Journal Vol. 72 No. 3. [Online]. Tersedia: http://www.edgj.org/index.php/EDGJ/ article/view/49/48. [23 April 2018].

Shadiq, F. (2009). Geometri Dimensi Dua dan Tiga. Jogyakarta: PPPPTK MATEMATIKA. [Online]. Tersedia: https://www.google.co.id/url?/site/ebookmatematika/geometri DimensiDuadanTiga.pdf. [25 Januari 2018]. 
Siswanto, R.H., dan Kusumah, Y.S. (2017). Peningkatan Kemampuan Geometri Spasial Siswa SMP Melalui Pembelajaran Inkruisi Terbimbing Berbantuan Geogebra. JPPM Vol. 10 No. 1. [Online]. Tersedia: https://jurnal.untirta.ac.id/index. hph. [1 Desember 2017].

Turgut, M., dan Yilmaz, S. (2012). Relationships Among Preservice Primary Mathematics Teachers' Gender, Academic Success and Spatial Ability. International Journal of Instruction Vol. 5 No. 2. [Online]. Tersedia: https://eric.ed.gov/?id=ED533781. [23 April 2018].

Wai, J., Lubinski, D., dan Benbow, C.P. (2009). Spatial Ability for STEM Domains: Aligning Over 50 Years of Cumulative Psychology Knowledge Solidifies Its Importance. Jurnal of Educational Psychology Vol. 101 No. 4. [Online]. Tersedia: http://psycnet.apa.org/doiLanding?doi=10.1037/a00 16127. [23 April 2018].

Yilmaz, H.B. (2009). On The Development and Measurement of Spatial Ability. International Electronic Journal of Elementary Education Vol. 1, Issue 2. [Online]. Tersedia: https://www.iejee.com/index.php/IEJEE/. [30 November 2017]. 